\title{
OPTIMALISASI BANDWIDTH DENGAN SQUID 2.7 STABLE 6 DAN MIKROTIK PADA JARINGAN HOTSPOT RAJAWALI INTERNET
}

\author{
Faruq Ali Sabana ${ }^{1)}$, Yodi ${ }^{2)}$ \\ ${ }^{1}$ Sistem Informasi, STMIK Putera Batam, Jl. R. Soeprapto Muka Kuning \\ Email: faruqsabana@yahoo.com \\ 2Sistem Informasi, STMIK GICI Batam, Komp. Bt. Aji Centre Park Batam \\ Email: yodilabs@gmail.com
}

\begin{abstract}
Bandwidth optimation with QOS (Quality of Service) in RouterOS that integrated with a cache server in which there is already installed Squid 2.7 Stable 6. And the result obtained is a new system has been able to optimize the bandwidth which is owned by the object of research. It can be concluded that the new system can replace the old system.
\end{abstract}

\section{Abstrak}

Tujuan penelitian ini adalah adanya optimalisasi bandwidth dengan QOS (Quality of Service) pada Mikrotik RouterOS yang terintegrasi dengan sebuah cache server dimana didalamnya sudah terinstal Squid 2.7 Stable 6. Dan hasil yang diperoleh adalah sistem baru telah mampu mengoptimalkan bandwidth yang dimiliki oleh objek penelitian. Sehingga dapat disimpulkan bahwa sistem baru dapat menggantikan sistem lama yang sedang berjalan.

Keyword: Internet, Squid, Bandwith, Optimasi

\section{PENDAHULUAN}

Beberapa tahun belakangan ini perkembangan internet di kota Batam semakin semarak seiring dengan kebutuhan masyarakat akan perlunya informasi dan komunikasi yang reliable. Didukung dengan niat Pemerintah Kota Batam untuk menjadikan Batam sebagai kota digital, saat ini telah banyak bermunculan penyedia jasa layanan internet dengan ruang lingkup yang bervariasi.

Rajawali Internet sebagai penyedia layanan internet dengan basis jaringan RT/RW Net saat ini telah menjangkau konsumen dengan pemakaian personal pada sekala menengah ke bawah. Meskipun skala jaringan yang dimiliki tidak terlalu luas, Rajawali Internet selalu berusaha meningkatkan kepuasan dan loyalitas pelanggan dengan cara membangun sistem jaringan yang memiliki kualitas koneksi yang stabil. Dan saat ini memiliki lebih dari 40 pelanggan dengan lokasi dan kebutuhan internet yang berbeda - beda. Dalam membangun koneksi tanpa kabel (wireless) yang stabil, Rajawali Internet selalu menjaga kualitas jaringan antara server dan pelanggan serta memberikan kuota bandwidth yang sesuai dengan kebutuhan.

Bandwidth internet yang ada dalam aktifitas sehari-hari sering kali 
digunakan untuk memenuhi beberapa layanan yang popular, terutama web, mail dan IRC. Web yang berada protokol http tentunya memegang porsi terbesar, mail nomor dua setelahnya. IRC memang merupakan layanan yang popular tetapi sama sekali tidak menghabiskan bandwidth.

Guna meningkatkan kualitas bandwidth, para penyedia jasa layanan internet pada umumnya memperbesar atau menambah porsi bandwidth yang mereka miliki. Namun di Indonesia saat ini harga bandwidth yang masih cukup mahal sehingga menambah bandwidth terkadang semakin menambah beban keuangan organisasi. Dengan mahalnya harga, solusi menambah bandwidth tentu saja bukanlah solusi yang tepat bagi Rajawali Internet saat ini.

\section{Rumusan Masalah}

Setelah melakukan penelitian, penulis menemukan beberapa permasalahan dalam mekanisme penghematan dan pengalokasian bandwidth kepada pelanggan, yaitu :

a. Apakah selama ini bandwidth yang dimiliki mampu melayani permintaan pelanggan?

b. Apakah Rajawali Internet dapat melakukan pembagian bandwidth sesuai dengan skenario yang diinginkan?

c. Sejauh mana efektifitas penerapan mekanisme Bandwidth Control dalam melayani para pelanggan?

d. Apakah Rajawali Internet sudah menggunakan mekanisme tambahan guna mendukung kinerja sistem yang berjalan didalam jaringan?

\section{Tujuan Penelitian}

Mengacu pada rumusan masalah yang telah dijabarkan pada subbab sebelumnya, dalam penelitian ini penulis memiliki tujuan sebagai berikut :

a. Dengan bandwidth yang dimiliki saat ini, Rajawali internet diharapkan mampu melayani permintaan dari pelanggan. Yang dimaksud permintaan pelanggan adalah permintaan yang bersifat teknis yakni berupa paket - paket data yang dikirim ke router (upload) maupun paket-paket data yang diminta (download) oleh komputer pelanggan.

b. Optimalisasi router Mikrotik RouterOS dimana saat ini Mikrotik menjadi primadona dalam dunia jaringan karena kemampuannya dalam menangani lalu lintas data dalam sebuah jaringan. Terutama jaringan bersekala kecil dan menengah.

c. Selain optimalisasi dalam implementasi Quality of Service (QOS) yang dilakukan oleh Mikrotik, penelitian juga bertujuan untuk mendapatkan solusi penghematan bandwidth dengan menerapkan sistem baru dengan menggunakan Squid 2.7 Stable 6 yang terpasang pada subuah Linux OS.

d. Dengan perpaduan Mikrotik Router dan Squid 2.7 Stable 6 yang terpasang pada Linux OS, diharapkan tujuan organisasi dapat tercapai yakni kualitas layanan dan koneksi yang stabil serta keuntungan bagi bagi organisasi.

\section{Teori Pendukung}




\section{Optimalisasi}

Optimalisasi mengandung makna membuat suatu sistem menjadi lebih baik dan menguntungkan sehingga tujuan organisasi dapat tercapai. Tentunya optimalisasi akan sesuai dengan yang diharapkan jika telah melalui berbagai macam proses, diantaranya proses yang ditinjau dari sudut ekonomi.

\section{Bandwidth}

Bandwidth adalah Besaran yang menunjukkan seberapa banyak data yang dapat dilewatkan dalam koneksi melalui sebuah network atau lebar pita atau kapasitas saluran informasi atau kemampuan maksimum dari suatu alat untuk menyalurkan informasi dalam satuan waktu detik (Jack Febrian, 54)

Bandwidth adalah konsep pengukuran yang sangat penting dalam jaringan, tetapi konsep ini memiliki kekurangan atau batasan. Batasan ini dipengaruhi oleh panjang media yang dipakai, kecepatan maksimal yang dapat dipakai, maupun perlakuan khusus terhadap media yang dipakai.

\section{Hotspot}

Hotspot atau disebut juga hotspot wifi dalam konsep jaringan komputer dapat diartikan jangkauan dari jaringan $\mathrm{WiFi}$, digunakan untuk interkoneksi tanpa kabel antar berbagai perangkat memiliki perangkat wireless sebagai media untuk berkomunikasi.

The Cell atau blok pembangun dasar suatu WLAN adalah area tempat terjadinya komunikasi wireless dengan jaringan. Area cakupan tergantung pada kekuatan sinyal dan karakteristik fisik lingkungan, misalnya ketebalan dinding atau struktur permukaan bumi. Laptop, PDA, dan workstation yang telah dilengkapi kemampuan wireless, dapat bergerak di dalam sel ini dengan akses ke jaringan seolah-olah mereka merupakan bagian Ethernet yang berkabel. WLAN memiliki kelebihan yaitu dapat memperluas jangkauan jaringan berkabel dan menyediakan konektivitas ke jaringan yang tidak dapat memungkinkan menggunakan jaringan kabel.

\section{Chace Server}

Chace server adalah suatu tempat untuk menyimpan data yang pernah diakses secara sementara. Mekanisme ini berfungsi untuk mempercepat transfer data yang telah disimpan dengan harapan jika data yang sama diakses, maka transfer data akan semakin cepat (Jack Febrian, 79)

Dalam topologi sebuah jaringan, biasanya cache server diletakkan antara workstation dan webserver dimana dalam hal ini interface yang menghubungkan jaringan dengan koneksi internet. Data yang tersimpan disebut object cache.

\section{Quality of Service (QOS)}

Quality of service memiliki arti bahwa sebuah router memberikan prioritas dan pembagian lalu lintas data dalam jaringan. QOS tidak hanya melakukan pembatasan saja, tetpai lebih cenderung kepada qualitas lalu lintas data dalam jaringan. (mikrotik manual,238)

\section{Mangle}

Mangle berfungsi untuk memberikan tanda kepada paket yang 
nantinya akan digunakan untuk melakukan berbagai proses, seperti simple queue atau queue tree. (Mikrotik manual,313)

Dalam membuat mangle yang perlu diperhatikan adalah alur dan jenis paket dalam jaringan. Kita harus tahu darimana arah paket masuk dan akan keluar. Dengan mengetahui jenis dan alur jalannya sebuah paket, maka kita akan dapat menandai paket paket yang akan digunakan.

\section{NAT (Network Address Transtlation)}

NAT adalah fasilitas yang berfungsi untuk menggantikan sumber dan (atau) alamat IP tujuan dari paket IP. Hal ini paling sering digunakan untuk mengaktifkan beberapa host di jaringan kita agar dapat mengakses internet melalui IP publik. Selain itu NAT juga berfungsi untuk melakukan komunikasi di dalam jaringan ataupun keluar jaringan. LAN yang menggunakan NAT disebur natted network dimana setiap natted network harus memiliki gateway agar host dalam jaringan dapat berkomunikasi.

\section{METODE PENELITIAN}

Penelitian dilakukan dengan metode penelitian lapangan.

a. Wawancara

Yaitu pengumpulan data yang dilakukan dengan cara melakukan tanya jawab dengan pelanggan Rajawali Internet yakni menyangkut kepuasan terhadap layanan Rajawali Internet. Selain itu penulis juga melakukan wawancara dengan administrator maupun pemilik Rajawali Internet tentang kendala mereka dalam melayani permintaan dari pelanggan.

b. Pengumpulan data-data yang relefan

Dalam hal ini penulis mengumpulan data - data dilapangan berupa :

- catatan-catatan system (sytemlog)

- Hasil monitoring lalu lintas data dari server ke pelanggan.

- Hasil uji bandwidth yang dilakukan pada sisi pelanggan.

2. Tinjauan Pustaka (Library Research)

Penulis mengumpulakan liteartur - literatur dari berbagai macam sumber. Baik literatur yang berasal dari buku maupun internet. Literatur ini nantinya akan digunakan penulis dalam menganalisa data - data yang terdapat di lapangan

\section{Objek Penelitian}

Rajawali Internet adalah peyedia jasa layanan internet berbasis internet kerakyatan atau yang disebut RT/RW Net. RT/RW Net adalah sebutan jaringan internet murah dengan menggunakan sambungan wireless ataupun kabel. Membangun RT/RW Net adalah suatu konsep dimana beberapa komputer dalam suatu perumahan atau blok dapat saling berhubungan dan dapat berbagi data serta informasi. Konsep lain dari RT/RW Net adalah memberdayakan pemakain internet dimana fasilitas internet tersedia selama 24 jam sehari selama sebulan dimana biaya yang akan dikeluarkan akan murah karena semua biaya pembangunan 
infrastruktur, operasional dan biaya langganan akan ditanggung bersama.

Selain dilengkapi dengan peralatan-peralatan baru, Rajawali Internet juga mencoba membuat variasi layanan kepada pelanggan dengan menerbitkan paket voucher, paket bulanan, serta paket bulanan dengan peraralatan yang dipinjamkan oleh pihak Rajawali Internet.

\section{HASIL DAN PEMBAHASAN}

\section{Implementasi Rancangan Topologi Jaringan}

Sebelum

mengimplementasikan rancangan yang ada, terlebih dahulu penulis menentukan topologi jaringan yang baru. Dalam sistem baru yang nantinya akan dibangun, pada topologi jaringan Rajawali Internet akan ditambahkan komponen baru yaitu cache server.

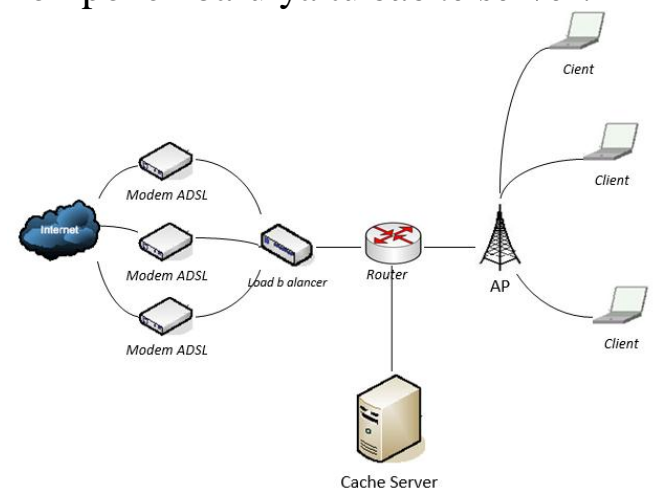

Gambar. 1. Topologi Jaringan Baru

Rajawali internet

Dengan posisi router berada di tengah lalu lintas paket data, maka akan mempermudah administrator untuk melakukan monitoring lalu lintas data dari segala arah.

\section{Pengalamatan IP}

Pengalamatan IP diterapkan dengan tujuan untuk memberikan identifikasi secara unik pada setiap mesin di dalam network. Bagian dari alamat ini haruslah unik karena alamat node mengidentifikasikan sebuah mesin tertentu yang merupakan group atau dapat juga disebut dengan alamat host.

Pengalamatan IP dibuat berdasarkan kebutuhan setiap jaringan. Hal ini perlu dilakukan dengan alasan :

a. Karena semakin banyak alokasi alamat IP pada jaringan yang membutuhkan sedikit alamat IP, maka respon jaringan akan berkurang. Hal ini disebabkan paket yang dikirim terlalu banyak melakukan pengecekan terhadap semua alamat yang seharusnya tidak perlu dilakukan dan tentu saja hal ini berakibat terhadap beban kerja protokol menjadi lebih berat.

b. Selain itu, semakin banyak alamat IP yang tidak digunakan, maka memungkinkan pihak-pihak tertentu untuk memasuki jaringan tanpa seijin dari Rajawali Internet.

Mendasari kedua hal tersebut diatas, maka Rajawali Internet perlu membuat pengalamatan IP sebagai berikut:

a. Pengalamatan IP workstation/ hotspot

IP address : :10.10.9.0/24

Subnet Mask : 255.255.255.0

Default Gateway: 10.10.9.254

b. Pengalamatan IP chace server

IP address: 192.168.12.0/29

Subnet Mask: 255.255.255.248

Default Gateway: 192.168.12.6

Pengalamatan IP untuk cache server maksimal adalah sebanyak 5 alamat ip dan 
alamat IP akan di bagikan kepada cache server sebanyak 2

c. Pengalamatan IP load balancer IP address : : 192.168.2.0/30 Subnet Mask: 255.255.255.252 Default Gateway: 192.168.2.2 Pengalamatan IP untuk cache server maksimal adalah sebanyak 2 alamat ip dan 1 alamat IP akan di bagikan kepada load balancer

\section{Pengalokasian bandwidth}

Pengalokasian bandwidth adalah prosedur yang perlu diterapkan berdasar pada jumlah dan kapasitas bandwidth yang dimiliki yang kemudian akan dibagikan kepada workstation sebesar jumlah yang diinginkan. Dengan menggunakan rancangan HTB (Hierarchical Token Bucket), simple queue dan borrow bandwidth, maka dapat diuraikan sebagai berikut:

a. Bandwidth Parent

Bandwidth yang dimiliki oleh parent adalah keseluruhan jumlah bandwidth yang berada dalam kelas layanan. Jika seluruh bandwidth yang dimiliki oleh Rajawali Internet akan digunakan untuk layanan hotspot maka:

- Maximal limit download $3 \mathrm{M}$.

- Maximal limit upload768 kbps.

\section{b. Bandwidth child}

Banwidth child adalah jumlah bandwidth yang akan diberikan kepada Pengujian Sistem yang Baru

Selanjutnya adalah tahapan uji coba sistem yang baru dimana dalam workstation atau pelanggan. Jika Rajawali Internet memilki 60 pelanggan, maka total bandwidth tidak harus dibagi dengan total pelanggan. Dengan parameter limit at, maka total bandwidth cukup dibagi dengan jumlah maksimal user aktif pada jam. Menurut data penulis dengan maksimum user aktif padam jam sibuk sebanyak 25 user, maka dapat diasumsikan pengalokasian bandwidth kepada pelanggan sebagai child adalah

- Maximal limit download 3M

- Maximal limit upload 768 kbps

- Limit at download $117 \mathrm{kbps}$

- Limit at upload $28 \mathrm{kbps}$

\section{c. Borrowed bandwidth}

Yang dimaksud borrowed bandwidth adalah jumlah bandwidth yang dapat dipinjamkan oleh parent kepada child. Jadi dalam konsep HTB (Hierarchical Token Bucket) hal yang juga perlu diperhatikan adalah jumlah bandwidth parent tidak boleh seluruhnya habis dibagi oleh jumlah user maksimal yang aktif dalam jam sibuk.

Jika dalam perencanaan jumlah bandwidth parent $3 \mathrm{Mbps}$ dan total jumlah bandwidth user aktif adalah sebesar 2925 kbps, maka besar borrowed bandwidth adalah sebagai berikut:

- Borrowed bandwidth download $147 \mathrm{kbps}$

- Borrowed bandwidth upload $68 \mathrm{kbps}$

uji coba bandwidth parent yang dialokasikan untuk simulasi adalah sebesar 512 kbps dengan jumlah user 
sebanyak 3 user. Alokasi yang digunakan adalah:

Bandwidth parent:

a. Maximal limit download 512 kbps

b. Maximal limit upload $128 \mathrm{kbps}$ Bandwidth child dengan jumlah user sebanyak 3:

a. Maximal limit download 512 kbps

b. Maximal limit upload 128kbps

c. Limit at download $128 \mathrm{kbps}$

d. Limit at upload $32 \mathrm{kbps}$

e. Borrowed bandwidth download $128 \mathrm{kbps}$ f. Borrowed bandwidth upload 32 kbps

Pengaturan bandwidth yang diinginkan adalah jika terdapat 1 user online, maka semua bandwidth parent akan digunakan oleh child. Jika terdapat 1 atau lebih user online, maka bandwidth parent secara otomatis akan terbagi rata ke child dengan CIR sebesar 128 kbps. Dan apabila user mendownload file dari server asal, maka akan terlimit oleh simple queue. Namun jika user mendownload file yang berada pada cache server, maka user dengan leluasa mendapatkan file yang diinginkan.

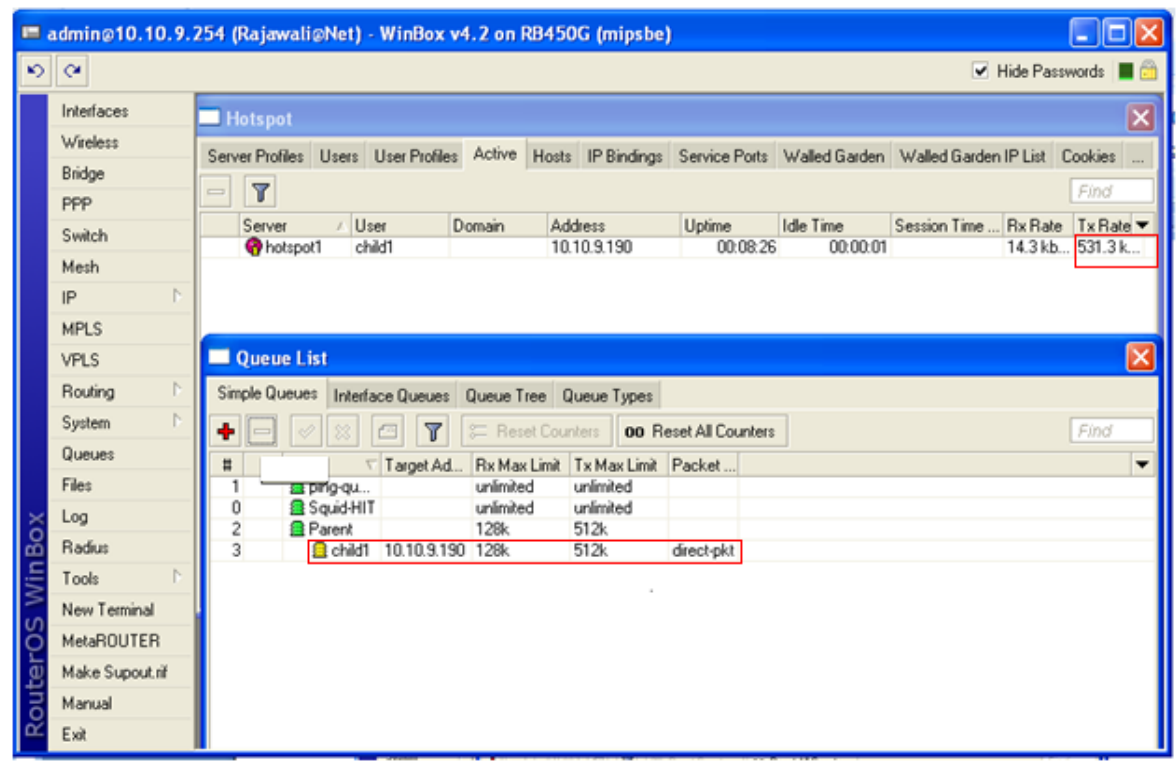

Gambar 2. Kondisi antrian dengan satu user aktif

Dalam gambar 2 dapat dilihat bahwa dengan kondisi satu user aktif, maka user mendapatkan seluruh bandwidth yang dimiliki oleh parent 


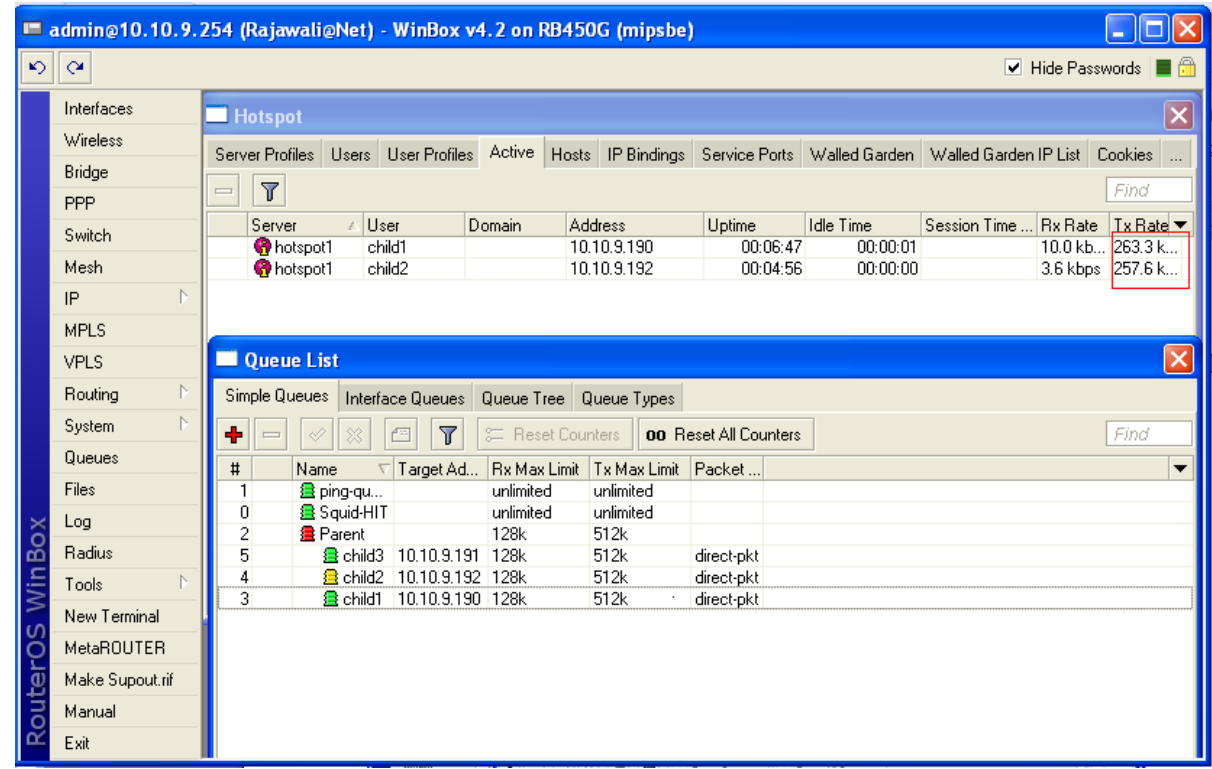

Gambar 3 Kondisi antrian dengan dua user aktif

Dalam gambar 3 dapat dilihat bahwa dengan kondisi dua user aktif, maka

user membagi seluruh bandwidth yang dimiliki oleh parent sama besar.

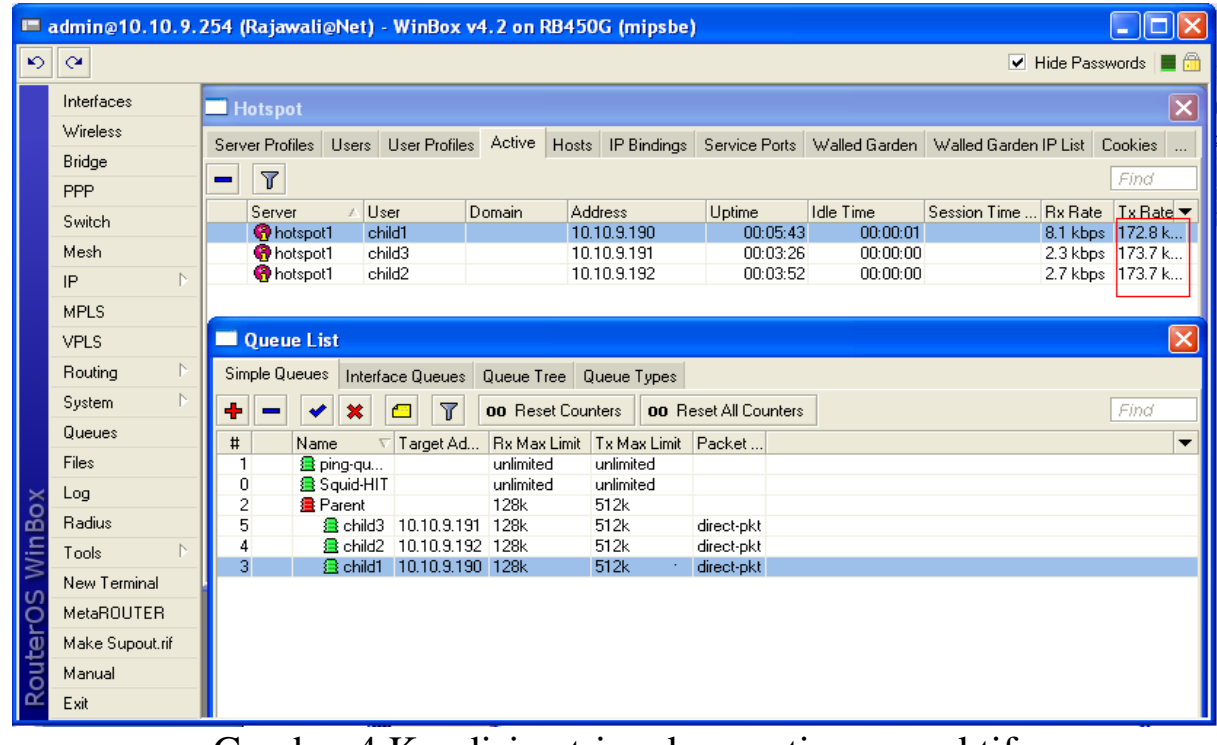

Gambar 4 Kondisi antrian dengan tiga user aktif

Dalam gambar 4 dapat dilihat bahwa dengan kondisi tiga user aktif, maka user membagi seluruh bandwidth yang dimiliki oleh parent sama besar. Ini juga akan berlaku jika terdapat 4 atau lebih user aktif.
Selain metode pengaturan bandwith dengan metode HTB, penulis juga melakukan uji coba terhadap kemampuan respon dari cache server dimana dalam gambar 5 dan gambar 6 dapat dibandingkan kualitas download 
yang diterima oleh workstation ketika melakukan download dengan file yang sama. Pada gambar 5 terlihat bahwa ketika workstation melakukan download ke server asal dengan menggunakan bandwidth yang diterima dari Telkom speedy dan akan mendapatkan limitasi banwidth dari router. Namun jika file sudah tersimpan di dalam cache server, maka workstation dapat dengan leluasa mendapatkan bandwidth yang bersifat lokal seperti yang terlihat pada gambar 6

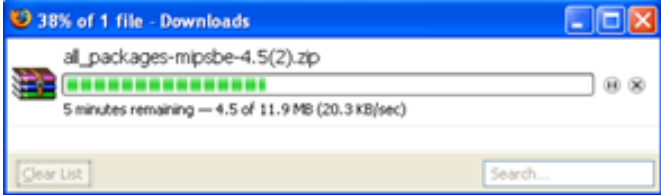

Gambar 5 Kondisi saat melakukan download ke server asal

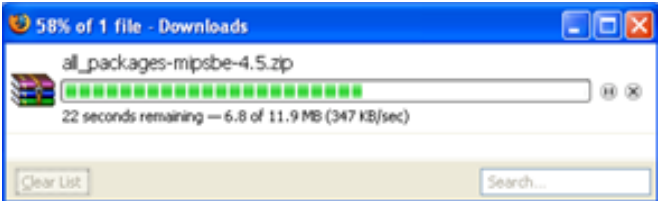

Gambar 6 Kondisi saat melakukan download ke cache server

Adapun gambaran log dari hasil cache yang berhasil disimpan adalah sebagai berikut
Graph of TCP Accesses (5 minute total)

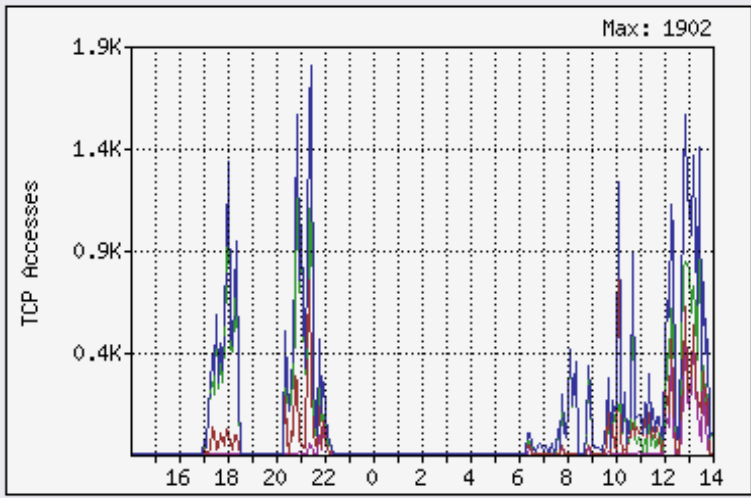

Gambar 7 Grafik jumlah file yang berhasil disimpan
Pada Gambar 7 tentang statistic cache server dapat disimpulkan bahwa cache server telah mampu meyimpan objek kurang lebih sebesar 28 persen dari total objek yang diakses oleh workstation ke server asal. 
Graph of TCP Transfers (5 minute total)

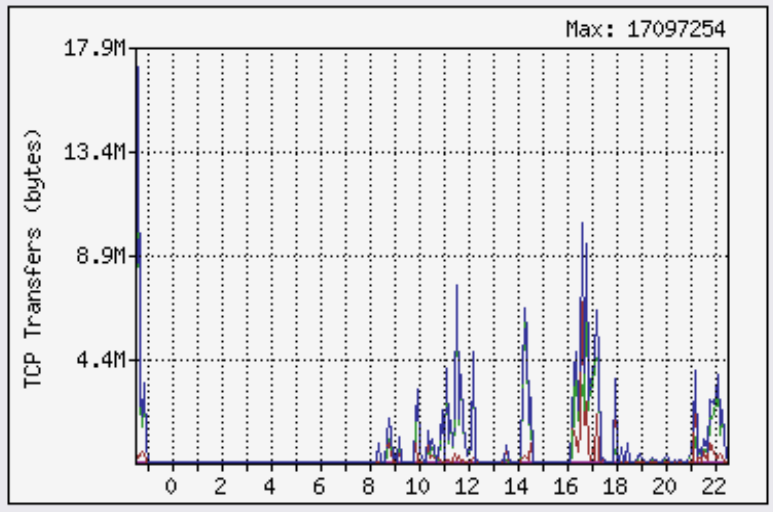

Total Transfers: $204.6 \mathrm{Mb}$

Average Transfers: $8.5 \mathrm{Mb}$ per hour

Total Cache Hits: $42.7 \mathrm{Mb}$

Average Cache Hits: $1.7 \mathrm{Mb}$ per hour \% Cache Hits: $20.89 \%$

Total Cache IMS Hits: $121.7 \mathrm{~Kb}$ Average Cache IMS Hits: $5 \mathrm{~Kb}$ per hour

Total Cache Misses: $161.8 \mathrm{Mb}$ Average Cache Misses: $6.7 \mathrm{Mb}$ per hour \% Cache Misses: $79.1 \%$

Gambar 4.18 Grafik jumlah file yang berhasil ditransfer

Pada grafik diatas dapat disimpulkan bahwa cache server telah mampu mengirim objek kurang lebih sebesar 20 persen dari total objek yang disimpan kepada klien.

\section{Analisa hasil implementasi sistem}

Setelah melakukan serangkaian tahapan implementasi, maka untuk memastikan keberhasilan sistem baru maka perlu dilakukan perbandingan antara sistem lama dan sistem baru. Perbandingan sistem yang terdapat dalam tabel 4.8 merupakan gambaran sistem baru dan sistem lama berdasarkan faktor pembanding tertentu . Dengan gambaran yang didapat, maka dapat diambil kesimpulan umum mengenai sistem terbaik yang akan diambil .

\begin{tabular}{|c|c|c|c|}
\hline \multirow{2}{*}{ NO } & \multirow{2}{*}{ FAKTOR PEMBANDING } & \multicolumn{2}{|c|}{ URAIAN } \\
\hline & & SISTEM LAMA & SISTEM BARU \\
\hline \multirow[t]{4}{*}{1} & Hardware & Modem ADSL, Load & Modem ADSL, Load \\
\hline & & Balancer, Router, Ac- & Balancer, Router, Ac- \\
\hline & & ces point, antena & ces point, antena, \\
\hline & & & Cache server \\
\hline \multirow[t]{3}{*}{2} & Sofware dalam sistem & Mikrotik RouterOS & Mikrotik RouterOS \\
\hline & & & IPCop 1.4 .20 dengan \\
\hline & & & Squid 2.7 Stable 6 \\
\hline 3 & Total Bandwidth yang dimiliki & $3 \mathrm{Mbps}$ & $3 \mathrm{Mbps}$ \\
\hline 4 & Quality of Service (QOS) & tidak ada & HTB \& simple queue \\
\hline 5 & Maximum Information Rate (MIR) & unguarantee & $768 \mathrm{kbps} / 3 \mathrm{Mbps}$ \\
\hline 6 & Commited Information Rate (CIR) & unguarantee & $28 \mathrm{kbps} / 117 \mathrm{kbps}$ \\
\hline \multirow[t]{2}{*}{7} & Accelerator sys tem untuk work & tidak ada & Cache server \\
\hline & station & & \\
\hline \multirow[t]{2}{*}{8} & Saved bandwidth / bandwidth & tidak ada & $20 \%$ s/d $50 \%$ \\
\hline & yang dapat dihemat & & \\
\hline
\end{tabular}

Tabel 8 Perbandingan sistem baru dan lama 


\section{Analisa Produktifitas}

Produktifitas dapat digambarkan dalam dua pengertian yaitu teknis dan finansial. Produktifitas secara teknis dapat digambarkan sebagai efisiensi produksi dalam pemakaian ilmu dan teknologi. Sedang produktifitas fanansial adalah lebih cenderung kepada pengukuran output dan input yang telah dihitung. Produktifitas akan maksimal jika faktor efisiensi dan efektifitas dapat dioptimalisasikan dengan baik sehingga keuntungan perusahaan akan meningkat.

\section{Segi Efisiensi}

Analisa efisiensi produktifitas pada sistem baru pada subbab ini akan membahas analisa efisiensi secara teknis dan finansial.

a. Analisa efisiensi teknis

Mengacu pada perbandingan sistem baru dan lama, dapat digambarkan bahwa sistem baru lebih efisien dalam hal penggunaan teknologi. Hal ini mengacu pada alasan sebagai berikut :

1. Adanya implementasi QOS (Quality of service) pada router dimana sebelumnya aplikasi ini tidak digunakan di dalam sistem lama. Padahal fitur QOS (Quality of service) ini sudah terdapat pada Mikrotik RouterOS yang dimiliki Rajawali Internet.

2. Adanya jaminan bandwith bagi wokstation dimana workstation tidak perlu lagi khawawatir apabila bandwidth yang ada terpakai oleh beberapa workstation saja.

3. Terdapat penambahan teknologi baru yaitu penambahan cache server. Keberadaan cache server ini sangant membantu kinerja jaringan dengan memberikan waktu respon lebih cepat dalam melayani permintaan dari workstation.

b. Analisa efisiensi finansial

Dalam melakukan analisa dan mengukur suatu sistem,maka sebuah sistem dapat dikatakan efisien adalah perbandingan rasio antara jumlah input yang direncanakan dengan jumlah input yang digunakan. Dalam konsep bandwidth pada Rajawali Internet, sistem baru mampu menghemat bandwidth kurang lebih sebanyak 20 $\%$ sampai dengan $50 \%$. Dengan asumsi tersebut dapat digambarkan :

$$
\begin{aligned}
\text { Efisiensi bandwidth } & =\frac{\text { Jumlah bandwidth yang direncanakan }}{\text { Jumlah bandwidth yang direncanakan- saved bandwidth }} \\
& =\frac{3072 \mathrm{kbps}}{3072 \mathrm{kbps}-(3072 \mathrm{kbps} \times 20 \%)} \\
& =1.25
\end{aligned}
$$

Jadi dapat disimpulkan bahwa sistem baru 1,25 lebih efisiensi dari pada sistem lama.

\section{Segi Efektifitas}

Analisa efisiensi produktifitas pada sistem baru pada subbab ini akan membahas analisa efektifitas secara teknis dan finansial.

a. Efektifitas teknis 
Bahwa yang menjadi acuan dari sebuah efektifitas adalah tercapainya target yang dinginkan. Mengacu pada perbandingan sistem baru dan lama, dapat digambarkan bahwa sistem baru lebih efektif dalam hal penggunaan teknologi. Hal ini mengacu pada alasan bahwa target yang ingin dicapai adalah sistem mampu memberikan kualitas layanan yang handal kepada workstation. Dengan penerapan teknolgi QOS (Quality of Service) dan cache server, sistem mampu memberikan layanan yang terukur sesuai skenario yang dinginkan.

b. Efektifitas finansial

Dalam sistem yang baru, target utama sistem adalah mampu melayani pelanggan yang ada saat ini yakni 43 pelanggan. Dengan sistem baru, Rajawali Internet dapat memenuhi target tersebut. Bahkan sistem mampu mencapai target layanan sampai 60 pelanggan. Dengan pencapain target melebihi yang dinginkan, tentu saja sistem baru dapat dikatakan efektif.

\section{SIMPULAN}

a. Rajawali belum mampu memberikan kualitas bandwidth yang ideal bagi para pelanggannya. Hal ini dikarenakan router masih belum mampu memberikan jaminan bandwidth kepada setiap workstation. Selain itu, berdasar data yang ada, terlihat adanya proses tarik menarik banwidth antar satu pelanggan dengan pelanggan yang lainnya tanpa ada pengaturan yang jelas.

b. Dengan sistem lama yang sudah berjalan, diketahui bahwa Rajawali Internet belum mampu memaksimalkan kinerja Mikrotik RouterOS untuk melakukan pengaturan bandwidth secara optimal. Padahal Mikrotik RouterOS memiliki keunggulan dan kemudahan dalam hal pengaturan bandwidth yang ada dalam sebuah jaringan.

c. Sistem baru yang telah dirancang dan telah diuji cobakan terbukti mampu melakukan pengaturan bandwidth berdasarkan skenario yang diinginkan oleh pihak perusaahan. Dengan metode HTB ( Hierarchical Token Bucket), router mampu secara fleksibel melakukan pengaturan bandwitdth pada jaringan Rajawali Internet.

d. Keberadaan cache server dalam sistem baru, telah banyak membantu kinerja sistem dalam jaringan. Hal ini terbukti dengan meningkatnya waktu respon sistem dalam melayani permintaan dari workstation. Selain waktu respon, cache server juga mampu melakukan penghematan bandwidth antara 20 persen sampai dengan 50 persen dari total kebutuhan bandwidth yang diperlukan.

\section{Saran}

a. Meskipun dengan sistem lama perusahaan masih dapat melayani pelanggan, namun penulis menilai layanan bandwidth yang ada berada pada tahapan kritis. Jika sistem lama terus dijalankan, maka akan berdampak pada ketidakpuasan pelanggan dan tentu saja hal ini sangat merugikan perusahaan. Oleh karena itu, untuk memaksimalisasi kenerja sistem dalam melayani permintaan pelanggan, dalam Mikrotik RouterOS perlu diterapkan fitur 
QOS (Quality of Service). Dengan HTB ( Hierarchical Token Bucket) dan sistem antrian simple queue, diharapkan bandwidth yang dimiliki dapat melayani kebutuhan pelanggan dengan baik. Namun diluar dari keunggulan dari sistem baru yang dibuat, penulis masih kesulitan dalam melakukan dyinamic simple queue pada aplikasi hotspot. Dalam dyinamic simple queue, administrator tidak perlu menambahkan rule simple queue untuk setiap pelanggan secara manual. Dengan dynamic simple quеие, setiap pelanggan yang telah $\log$ in secara otomatis akan menjadi child dari kelas parent.

b. Guna meningkatkan performa sistem jaringan Rajawali Internet, Mikrotik RouterOS yang terinstal dalam RB450G saat ini dapat melakukan kerja sama dengan sistem lain yakni cache server. Berdasar pada analisa, rancangan dan hasil ujicoba yang telah dilaksanakan, perlu kiranya ditambahkan sebuah cache server pada sistem jaringan Rajawali Internet. Penambahan ini diharapkan mampu meningkatkan waktu respon system dalam Andrew Tiade, ST, ebook, Jaringan mputerMikrotik RouterOS V.3 Reference Manual Mikrotik Company http://www.tsl.state.tx.us http:// www.squid-cache.org melayani permintaan dari pelanggan serta dapat menghemat komsumsi bandwith yang dimiliki oleh Rajawali Internet. Namun dari sistem cache server yang telah dibuat, penulis mengalami kesulitan dalam melakukan mounting atau partisi single hardisk dalam IPCop secara manual. Partisi hardisk ini perlu dilakukan digunakan untuk meningkatkan kemampuan baca tulis hardisk dalam melayani klien.

\section{Daftar Pustaka}

Rahmat Rafiudin, 2008, Squid

Koneksi Anti Mogok Penerbit Andi, Yogyakarta.

W.Purbo, Onno ,Adnan Basalamah, Ismail Fahmi, 2002, TCP/IP PT Elex Media Komputindo

Tanenbaum, Andrew. S, 2003, Jaringan Komputer Prenhallindo Jakarta Lukas,Jonathan, 2006, Jaringan Komputer Graha Ilmu Yogyakarta Yani, Ahmad, 2007, Panduan Membangun Jaringan Komputer Kawan Pustaka Dodi Maryanto, 2007, Optimasi Internet dengan Squid PT Elex Media Komputindo 